\title{
Martyna Grązka
}

The Institute of National Remembrance, Kraków, Poland

\section{Jewish Women in the Kraków Ghetto: an Outline of Research Issues}

\section{Abstract}

This article describes the very varied, and at times, surprising role of Jewish women in the Kraków Ghetto during World War Two.

\section{Keywords}

Jewish life in Kraków, ghetto, Jewish women, new roles of women.

The German concept of the so-called Final Solution of the Jewish question assumed no age nor sex division. Every Jewish man and woman was destined to die sooner or later. No exceptions were made and even a prominent position did not guarantee surviving the occupation. Hence, all regulations issued since the beginning of World War II (and even earlier - starting from the Nuremberg Laws) did not set any sex division among Jews. Age group criteria were introduced only to single out certain people e.g. those capable of work (so-called forced labour) or due to the order of wearing white armbands with an emblem - the Star of David. The Nazis did not follow set and existing cultural norms concerning issues such as the special treatment of women as weaker and gentler beings since their overall plan was the extermination of all Jews. Thus, men and women (and consequently - children) were rounded up and settled in the so-called Jewish districts or - where Einsatzgruppen operated - they were taken to isolated places to be $\operatorname{shot}^{1}$. It was decided over time to liquidate the ghettos and to gather Jews in various types of camps. In that case the ability to work was a decisive factor assessed on the basis of

1 R. Hilberg, Perpetrators, Victims, Bystanders: The Jewish catastrophe, 1933-1945, New York, 1992, p. 126 and n. 
age and general health. Therefore, sex was not the sole criterion. However, Raul Hilberg has emphasized by: "the route of annihilation was paved both by events experienced mainly by men and those which concerned primarily women. First of all, role change took place. Relations between people had also changed. Finally, there were differences in the experience of stress and traumas"2. It is this role change, expressed e.g. in family relationships or the professional status of Jewish women, that constitutes the subject of this article. This issue will be considered on the basis of source materials and memories from the Kraków Ghetto. Although there are researchers who claim that there is no need to listen only to women or only to men since Germans intended to exterminate all Jews, it is worthwhile to the perspective of one of these groups - in this case women - to see and analyze the specific problems and conditions related to gender ${ }^{3}$.

Historians researching the fate of Jewish women in occupied Kraków may use many various sources. These include materials created during World War II - mostly administrative files issued by Judenrat ${ }^{4}$ in Kraków and the office of Stadthauptmann of the city of Kraków ${ }^{5}$. These are mainly applications for Kennkarten (identity cards), letters on current official issues and censuses of the Kraków Ghetto population including such indicators as sex or occupation. There are also documents in the archive resources concerning assets taken over by Germans after liquidating Jewish associations, private companies etc. Moreover, records related to social care associations and institutions in occupied Kraków might be of value when considering the subject matter as they are fields of particular activity of women. Hence, it is necessary to study documents collected in the Jewish Historical Institute in Warszawa (ŻIH) concerning the functioning of the American Jewish Joint Distribution Committee (Joint) ${ }^{6}$

\section{Ibid.}

3 J. E. Miller, Love Carried Me Home: Women Surviving Auschwitz, Florida, 2000, p. 24; For more on this topic see: J. Stöcker-Sobelman, Kobiety Holokaustu. Feministyczna perspektywa w badaniach nad Shoah. Kazus KL Auschwitz-Birkenau, Warszawa 2011; A. Nikliborc, Uwięzione w KL Auschwitz-Birkenau. Traumatyczne doświadczenia kobiet odzwierciedlone w dokumentach osobistych, Kraków 2010.

4 Archiwum Żydowskiego Instytutu Historycznego (The Archive of the Jewish Historical Institute) - AŻIH, file no. 218, Jüdische Gemeinde Krakau.

5 AŻIH, file no. 228, Der Stadthauptmann der Stadt Krakau.

6 AŻIH, file no. 210, American Jewish Joint Distribution Committee (1939-1941). American Jewish Joint Distribution Committee has been functioning from 27 November 1914. It was established in the United States by local Jewish charities to bring aid to Jewish communities mainly 
and the Jewish Social Self-Help (ŻSS) ${ }^{7}$, as well as materials on the Union of Societies for the Care of Orphans and Abandoned Children (Centos) $)^{8}$.

Apart from the above-mentioned source materials, post-war accounts archived mainly in the ŻIH in Warsaw ${ }^{9}$ provide a lot of information about everyday life. More than 300 out of almost 860 memories from occupied Kraków were written by women. Due to the fact that these stories were told soon after the end of World War II, it may be seen that they are characterised by a high degree of emotion, yet indelible by the passage of time. In addition, in the archives of the Institute of National Remembrance (IPN) ${ }^{10}$ there are stories of Jewish men and women who survived the war in occupied Kraków. However, they have a different character as they take the form of statements made during interrogations by members of the Commission for the Prosecution of Crimes against the Polish Nation in Kraków ${ }^{11}$. They constitute an integral part of the documentation of trials against e.g. KL Płaszów concentration camp personnel and the commandant of this camp - Amon Göth. Therefore, a researcher will not receive answers to many troubling questions concerning widely understood customs on the basis of this type of sources. They lack descriptions of emotions and everyday situations in the analysed context i.e. studies on histories and changes in Jewish women's lives. These statements

from Central and Eastern Europe and Turkey. "The Joint" supported various charitable initiatives and social enterprises during World War I, as well as during the interwar period. Help provided by this organisation in World War II had a particular dimension.

7 AŻIH, file no. 211, Żydowska Samopomoc Społeczna. Żydowska Samopomoc Społeczna (Jewish Social Self-Help) - ŻSS initiated in May 1940, was part of Naczelna Rada Opiekuńcza (Central Social Council) chaired by Count Adam Ronikier. ŻSS operated in the whole territory of the General Government with the headquarters initially located in Warsaw, then eventually moved to Kraków. Money, food and medicine essential to ŻSS activity were obtained above all from Jewish philanthropic organisations from neutral countries such as Sweden and Switzerland, as well as from the International Red Cross and American Jewish Joint Distribution Committee. A part of the resources also came from grants for Naczelna Rada Opiekuńcza from the General Government administration.

8 AŻIH, file no. 200, Centrala Towarzystw Opieki nad Sierotami i Dziećmi Opuszczonymi (Centos). This organisation was called in short - Centos. Similarly to "The Joint", Centos already functioned in the pre-war period taking care of poor and orphaned Jewish children. Summer and day camps were organized for them. Moreover, the poorest children were fed and supplied with clothes and so-called basic need products. The main division of Centos was located in Warsaw but there were also local branches e.g. in Kraków. The activity of Centos was financed mainly from the resources provided by the American Joint Committee.

9 AŻIH, file no. 301, Accounts of Holocaust survivors.

${ }^{10}$ Instytut Pamięci Narodowej.

${ }^{11}$ Komisja Badania Zbrodni przeciwko Narodowi Polskiemu. 
were an element of the trial documentation, and therefore their purpose was to acquire materials and evidence incriminating Germans. That is why descriptions of war crimes committed by the SS and Gestapo officers predominate in the statements.

Another important source are diaries written during the war or directly after its end and stored at the $\dot{Z} \mathrm{IH}^{12}$. Eleven out of sixteen diaries concerning occupied Kraków and its surroundings, which are included in the mentioned collections, were produced by women and teenage girls. These are among others diaries of: Maria Steczko, Fela Schechter, Cesia Frymer, Pola Warszawska, Henia Karmel-Wolf, Berta Liebermann and Janina Hescheles. There are also important collections of accounts in foreign archives: Yad Vashem The Holocaust and Martyrs' and Heroes' Remembrance Authority in Jerusalem, the United States Holocaust Memorial Museum in Washington, and the USC Shoah Foundation Institute for Visual History and Education.

It is worthwhile to briefly characterise the term „Jewish woman” before moving on to further analysis. A girl who becomes 12 years old (12 years and 1 day as per her Hebrew date of birth) is regarded as a woman according to Orthodox Jewish tradition. This age regulation means that she is obliged to follow the commandments, and allowed to enter into marriage ${ }^{13}$. However, even in Orthodox communities girls of this age did not marry; in fact this limit was shifted to at least 17 years of age ${ }^{14}$. The rite of introducing girls to the world of women in Reform and Conservative communities is associated with a ceremony conducted in the synagogue - similar to Bar Mitzvah for boys - called Bat Mitzvah. Yet, it was not popularised in Central and Eastern Europe in the interwar period; it was not even known ${ }^{15}$. Therefore, the age of 12 would constitute a lower limit for the analysed group in accordance with the principles of Judaism.

Leaving aside the religious definition and taking into account the biological aspect - a 12-year-old has not yet fully developed anatomical and physiological features (menstruation) are clear signs of her feminity. Moreover, in fact she

${ }_{12}$ AŻIH, file no. 302, Pamiętniki.

${ }^{13}$ For more on this topic see: A. Unterman, Dictionary of Jewish Lore and Legend, London 1991; Encyclopedia Judaica, pod. red. F. Skolnik'a i M. Berenbaum'a, vol. 14, USA 2007 [women].

${ }^{14}$ A. Grupińska, Najtrudniej jest spotkać Lilit. Opowieści chasydzkich kobiet, Kraków - Budapest 2008, pp. 121-135.

${ }_{15}^{15}$ B. Wasserstein, W przededniu. Żydzi w Europie przed druga wojna światowa, Warszawa 2012, p. 139. 
is still not able to have children. One should also consider issues related to the development of social awareness and processes of mature thinking, as well as responsibility for one's deeds. Jean Piaget has demonstrated in his theory of cognitive development that the age of 12 is only a beginning of the formation of abstract thinking for a developing human. Only then does the process of understanding the possible existence of alternative views start, as well as the attempts to imagine them. The ability of abstract thinking also allows us to cross the boundaries of time and space, hence a young person might visualise the future and places they have never been $t^{16}$. It is essential that the moment when a child enters into this phase is determined by the culture and environment in which they are being brought up. Therefore, the abovementioned factors would point to an age older than 12 years as an indicator of passage from childhood to womanhood.

What is more, taking on a religious criterion would lead to an exclusion of a sizeable group of assimilated Jews rejecting the traditional approach and rites. And there was a significant number of assimilated Jews in interwar Kraków. Taking into account the legal aspect it should be mentioned that Germans set the age range for the Jewish population capable of working. It had been decided that people between 14 and 60 years of age are subject to forced labour. The age of 14 was appointed in pursuance of Implementation Order No. 2 issued on 11 December 1939 for the Regulation of 26 October 1939 for the Introduction of Forced Labour for the Jewish Population in the General Government ${ }^{17}$. Therefore, the indicated age limits designate a group of adults capable of effective work. KL Płaszów concentration camp commandant Amon Göth ordered on the day of the liquidation of the Kraków Ghetto that children under 14 years of age could not be kept in the camp ${ }^{18}$. He came to the conclusion that the children would not be able to work efficiently and hence were unnecessary in the camp designed as a large workplace for the economy of the Third Reich. In my opinion, it

16 J. Piaget, Studia z psychologii dziecka, Warsaw 2006, pp. 12-36.

${ }^{17}$ Verordnungsblatt des Generalgouverneurs für die besetzten polnichen Gebiete (Dziennik rozporzadzeń Generalnego Gubernatora dla okupowanych polskich obszarów) - Implementation Order No. 2 for the Regulation of 26 October 1939 for the Introduction of Forced Labour for the Jewish Population in the General Government, of 12 December 1939, pp. 246-248.

${ }^{18}$ IPN BU, NTN (Najwyższy Trybunał Narodowy), file no. 196/43, Relacja Felicji Friedman, k. 50; IPN BU, NTN, file no. 196/43, Akta w sprawie karnej Amona Götha, Zeznania Scheinbacha, k. 191; IPN BU, file no. NTN, 196/47, Zeznania dr med. Leona Steinberga, k. 82-83. An exception was made for 25 children of prominent people from the Kraków Ghetto. 
would be justified to define Jewish woman as a person who has reached the age of 14 considering various factors - cultural, religious, or social. Also in my previous research on a group of Jewish children from the occupied Krakow age of 14 constituted the upper age $\operatorname{limit}^{19}$. It is mainly related to the aspect of adaptation to social life and readiness to perform set social roles, as well as specific duties imposed by the notion of "being a woman". However, implementation of this age regulation (age 14) requires dividing the study group into several categories such as teenage girls, young women, women-mothers, older women, etc.

Women constituted the majority of Kraków inhabitants during pre-war period, and during the war and occupation. In 1931 a general census was conducted (second in the independent Poland). The collected data currently allows for analysis of the phenomenon of national minorities settled in Kraków of that time ${ }^{20} .45,828$ respondents declared to use one of the Jewish languages as their mother tongue. A little bit more - 23,340 people, including 11,473 men and 11,867 women - chose Yiddish, whereas 22,488 respondents - 11,020 men and 11,468 women - indicated Hebrew. This number constituted approximately $20.95 \%$ of the total population of Kraków in the early thirties of the twentieth century. A bigger group $-56,515$ people - declared to have religious affiliation and described themselves as followers of Judaism, what amounted to $25.8 \%$ of the population inhabiting the city according to statistical data. There were 27,608 men and 28,907 women among them. It should be added that respondents who called themselves the followers of Judaism also indicated other mother tongues e.g. 10,517 people $(5,055$ men and 5,462 women) stated Polish.

In autumn 1939, the occupires ordered the Jews of Kraków and nearby communities (e.g. Borek Fałęcki, Skawina, Prokocim) to register. The first census ordered by the Germans took place between 8 and 24 November and the second from 25 November to 31 December 1939. Approximately 68,482 Jews lived in Kraków and the surrounding areas according to the collected data. Children under the age of 16 constituted almost $28 \%$ of this number

${ }^{19}$ M. Grądzka, Przerwane dzieciństwo. Losy dzieci Żydowskiego Domu Sierot przy ul. Dietla 64 w Krakowie podczas okupacji niemieckiej, Kraków 2012, pp. 125-127.

${ }^{20}$ Drugi spis powszechny ludności z dn. 9 XII 1931 r. in: Statystyka Polski Seria C, Warszawa 1937, p. 13f; J. Bieniarzówna, J. M. Małecki, Dzieje Krakowa, vol. IV: Kraków w latach 1918-1939, Kraków 1997, p. 31; A. Chwalba, Dzieje Krakowa, vol. V: Kraków w latach 1939-1945, Kraków 2002, p. 95. 
i.e. 19,732 people $^{21}$. It should be noted that a significant number of Jews was displaced from the city of Kraków to smaller locations in the districts of Kraków, Radom and Lublin between the first half of 1940 and April 1941. The aim of this operation was to - use the terminology of the time - to "cleanse the city" so-called capital city of the General Governement of the Jewish people ${ }^{22}$. These resettlements led to a considerable mixing of the Jewish population in the city. Therefore, it is difficult to say how many of the Jews inhabiting the ghetto in Podgórze had still been living in Kraków in August 1939 and how many of this group moved to the city e.g. from the nearby towns.

Population statistics were still conducted even after the Ghetto in Kraków had been established. The first censuses were taken in May 1941 i.e. soon after the creation of the Jewish district. At that time there were 10,873 people in the Kraków Ghetto including 5,839 women and 5,034 men according to the data $\mathrm{kept}^{23}$. This number did not take into account people such as children and educators from the orphanage at 64 Dietla Street as both employees and charges of this institution could stay there for a few weeks longer until being moved to the ghetto at the end of May $1941^{24}$. Of course, the official statistics did not include those who originally came from the surrounding towns and hid in the Kraków Ghetto. Therefore, we are not able to determine the exact number of people living in the district at that time. In January 1942, 16,310 Jews lived in the ghetto, including 7,551 men and 8,759 women, according to other statistical data saved ${ }^{25}$. Whereas, according to the latest official census: in April 1942 17,163 people resided in the district - 7,726 men and 9,437 women ${ }^{26}$.

${ }^{21}$ AŻIH, file no. 228/11., Sprawozdanie dotyczace liczby ludności żydowskiej Krakowa (statistical data), k. 1f; A. Chwalba, Kraków w latach... (vol. V), p. 95.

${ }^{22}$ AŻIH, file no. 301/448, Relacja Leiba Salpetera; T. Wroński, Kronika..., p. 136; The lists of people resettled from Kraków at this time together with marked locations, where they were moved, are stored in AŻIH collections under file no. 228: Der Stadthauptmann der Stadt Krakau (Starosta Miasta Krakowa) and in APKr (Archiwum Państwowe w Krakowie - The National Archive in Kraków) collections.

${ }^{23}$ APKr, file no. SMKr, 744 (microfilm J 13 869), Die Bevölkerung des Judenwohnbezirkes in Krakau (Ludność dzielnicy żydowskiej w Krakowie) 1 maj 1941 r., k.15; R. Kotarba, Niemiecki obóz w Ptaszowie 1942-1945, Warszawa-Kraków 2009, p. 14.

${ }^{24}$ M. Grądzka, Przerwane dzieciństwo..., pp. 105-106.

${ }^{25}$ APKr, file no. SMKr, 744 (microfilm J 13 869), Die Bevölkerung des Judenwohnbezirkes in Krakau (Ludność dzielnicy żydowskiej w Krakowie) 1 stycznia 1942 r., k. 37-38.

${ }^{26}$ Ibid., Die Bevölkerung des Judenwohnbezirkes in Krakau (Ludność dzielnicy żydowskiej w Krakowie) 10 kwietnia 1942 r., k. 37-38. 
The Kraków Ghetto, covering a small area, created a specific framework for the existence of Jews enclosed within it: "Less than 20 streets formed a real city. It is indeed odd - how much energy is revealed by people cast out from society" ${ }^{27}$. Orders issued by Germans, constituting the implementation of their policy consistently aiming at the extermination of Jews, as well as the internal rules of ghetto life caused a change of pre-war social models and patterns. It concerned all strands of life, starting from everyday duties, relationships in a family, through a professional and religious sphere, ending at difficult aspects of morality and sexuality. Women took a special place in that process. The unfolding events and chaos of the war led to a situation where women often turned out to be stronger and more resistant to the conditions of that time. They became heads of families, taking a place naturally assigned to men. It was they who had to worry about obtaining material resources, food and medicine. They were also responsible for making decisions regarding family life. Taking over such traditional male roles concerned not only women - wives and mothers but also sisters and daughters.

A woman in traditional Jewish communities did not have very high status. She was dependent on a man most of her life - first on her father, and later on her husband ${ }^{28}$. Taking care of children and homestead was her primary role, whereas the ritual of lighting candles every Sabbath was the most important mitzvah for her. In fact, Orthodox women did not have a chance to become known in the public sphere. Indeed, they could earn money in order to enable their husbands to study the Torah and Talmud, but they were not allowed to perform any significant functions within the Jewish community ${ }^{29}$. Women in the traditional circles also received very basic education. Orthodox rabbis were of the oppinion that teaching women the Torah meant telling them how to be insidious and even false ${ }^{30}$. In return, women had greater knowledge on the world of non-Jews, with whom they met from time to time e.g. in trade relations. There is no doubt that the Jewish community living in prewar Kraków was diversified and was not limited to the area of the Kazimierz shtetl. Moreover, many Jews crossed the boundaries of the district especially

${ }^{27}$ S. Müller-Madej, Dziewczynka z listy Schindlera. Oczami dziecka, cz. I, Kraków 2001, p. 27.

${ }^{28}$ B. Wasserstein, W przededniu..., p. 138.

${ }^{29}$ For more on this topic see: A. Unterman, Dictionary of Jewish Lore and Legend, London 1991; Encyclopedia Judaica, pod. red. F. Skolnik'a i M. Berenbaum'a, vol. 14, USA 2007 [women].

${ }^{30}$ Ibid. 
during the interwar period, as well as abandoned rigid principles set by Judaism. One might find descriptions in post-war accounts that contradict the image of women, who are modest, quiet, uneducated and associated only with the household. For example:"Mummy read in German, she read in French - she learnt it at school. My parents were educated people" 31 or "At that time grandma was emancipated: she did not like the household, did not like to cook, did not like to clean ... She liked to earn money instead, spend time in cafés, receive visitors, and to dress nicely..." ${ }^{32}$. There are much more similar memories of Kraków Jews. Many organisations referring to left-wing and Zionist currents (generally not associated with the traditional, Orthodox approach) operated in the city itself, tempting especially young people with prospects for a different life in Poland or Palestine ${ }^{33}$. There is no doubt that even in such a modern city as Kraków, the role of a matchmaker was still popular in the thirties of the twentieth century ${ }^{34}$.

A traditional division into male and female professions was still functioning at the beginning of the war and in the first months of the existence of the Kraków Ghetto. Men were often doctors, builders, shoemakers, barbers, painters or carriers, while women either did not work at all or were employed as seamstresses, nannies, nurses and cleaners. This natural division did not apply to forced labour imposed by the occupier, in which case only age not sex, was significant. However, it sometimes happened that more prosperous families paid poorer people for working off their forced labour. There is no doubt that an employment profile was a crucial factor deciding on the possibility of staying in the ghetto. In the initial stage of the ghetto existence woman-mothers who had small children often stayed at home to take care of the offspring: their own, other women's from the family or the neighbourhood. It is difficult to determine the birth rate in the Kraków Jewish community because of two facts: insufficient source data and major population movements after the breakout of World War II. Nevertheless, it seems that it had been

${ }^{31}$ A. D. Pordes, I. Grin, Ich miasto. Wspomnienia Izraelczyków, przedwojennych mieszkańców Krakowa, Warsaw 2004, p 47.

32 Ibid., p. 33.

${ }^{33}$ For more on this topic see: M. Sean, Jewish life in Cracow 1918-1939, Portland, Oregon, 2004; K. Samsonowska, Wyznaniowe gminy żydowskie i ich społeczności w województwie krakowskim (1918-1939), Kraków, 2005; P. Trojański, Żydzi w województwie krakowskim 1918-1939. Studia statystyczne nad aktywnościa społeczno-zawodowa, Kraków 2009.

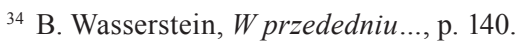


decreasing since the interwar period, this was particularly noticeable in less Orthodox families. Bernard Wasserstein formulated a hypothesis in his studies on that period that the birth rate declined in all Europe, including Central and Eastern European countries ${ }^{35}$. It was related to many factors e.g. economic, ideological, social, but it was also connected with emigration.

Jewish women left their households and took over professional functions alongside a progressive impoverishment of the population during World War II. Moreover, they became main breadwinners of the family. In a study concerning Jewish women and their attitudes from the documents collected in the underground Ringelblum Archive in Warsaw related to everyday life during the occupation, one can read as follows: "A Jewish woman entered into almost every sphere of life where she sometimes reached hegemony over a man and became a structural factor in a formation of our new economic and moral reality. She brings many patterns from her past experience to her individual and public activity but she bends this experience to new rules of living with subtle and astonishing intuition so that her actions gain the most positive effect in our conditions. However, a term "to survive" does not create borders of Jewish woman's efforts. She wants to build a foundation also for the future socio-economic revival, hence there is an urge to professions. The accomplishments of Jewish women in this field are particularly worth emphasising" ${ }^{36}$. Even though the above excerpt comes from the documents related to the Warsaw Ghetto, it is also comparable to the changes taking place in the life of Jewish women living in the Kraków Ghetto. In the extreme living conditions in the ghetto they interpreted and redefined the role of a perfect Jewish woman, who should be traditionally "modest, quiet and diligent, patient, obedient to God and her husband, should not notice her needs and remember about herself" ${ }^{\prime 3}$. They used all of these features, especially diligence and resourcefulness, to support and save the lives of their nearest and dearest, as well as their own.

There were cases that men broke down mentally, fell into depression or apathy under the influence of existing conditions, and then their roles were taken over by women - wives and daughters. Teenage Renia Knoll wrote in her

${ }^{35}$ Ibid., pp. 10-13.

${ }^{36}$ Archiwum Ringelbluma. Konspiracyjne Archiwum Getta Warszawy, compiled by K. Person, vol. 5, Getto warszawskie. Życie codzienne, Warsaw 2011, p. 195.

${ }^{37}$ A. Grupińska, Najtrudniej jest..., p. 124. 
diary that even though her father was a working man, he also was a gambler - he played cards with acquaintances, what had an impact on a household budget and family relations. "My daddy is a very good man [...] but he has a terrible disadvantage - he is a card player. From time to time he sits down at the table and plays day and night. [...] he must not be distracted because he shouts terribly" 38 . And her peer Halina Nelken recalled that she could not deal with running a household ${ }^{39}$. Women were not allowed to be employed on high positions at the office, so they became mostly manual workers. They could not also hold functions in the Judenrat. Some women, especially those with prewar connections and a very good education, had a chance to get better, more prominent positions, so they could improve the life of their family. A perfect example is a story of a mother of Stella Müller-Madej - Berta ${ }^{40}$. As the girl recalls:"Mummy has a good job. She works in a button factory in Agnieszki Street. Mrs. Holzinger is a commissioner of this company. [...] It has been said from the very beginning that Holzingers are decent Germans, Austrians. Mummy runs the office. Mrs. Holzinger does not interfere with anything and is fond of my mummy. They are even a bit alike. Thanks to the mummy's work we are doing quite well. Mrs. Holzinger brings great progs to the office and since mummy receives an individual ghetto pass, it is somehow easier for her to smuggle the goodies. Apparently, [she - translator] is perceived as "something" better at the gate control. No German coming to the office considered her to be Jewish"4t. Berta Müller might have gotten this position due to her perfect knowledge of German, her origin and "good looks". Not every Jewish woman in the Kraków Ghetto had such additional and at the same time distinctive advantages.

Judenrat clerks also created employment records analogous to population censuses taken in the Kraków Ghetto. Dates at which these statistics were compiled coincide with dates of the censuses i.e. May 1941, January and April 1942. Lists of employees were divided by sex and occupation. No specific profession was indicated and a list of 26 occupational groups was created e.g. "manufacturers of textiles", "building professions", "clothing professions",

${ }^{38}$ AŻIH, file no. 302/197, Pamiętnik Reni Knoll, k. 115-116.

${ }^{39}$ H. Nelken, Pamiętnik z getta w Krakowie, Toronto 1987, p. 123.

${ }^{40}$ The Müllers were an assimilated Jewish family. Berta (maiden name - Bleiweis) was of German descent. Her husband and Stella's father - Zygmunt Müller ran inter alia a glass factory at Stradom Street.

${ }^{41}$ S. Müller-Madej, Dziewczynka ..., p. 21. 
134 Volume 3 (2013) Number 2, p. 123-141

„home helpers and similar professions" ${ }^{\text {"42 }}$. Among these groups were professions with no employment recorded in any of these registers. These were the following fields: "hunting, forestry, fishing", "miners and similar", "theatre and film personnel". A lack of people working in the above-mentioned professions is not surprising taking into account the living conditions in the Kraków Ghetto. Occupations related to agriculture were at the beginning of the list of professions, in which only two women were employed according to the first census from May 1941. This number was at the same level in January 1942, whereas it increased to 16 women during the next census i.e. in April 1942. This might be connected with a seasonal character of some jobs, hence the increase of employment of women in agriculture in the spring of 1942. Professions associated with ceramics, masonry and glassmaking constituted another field, in which Jewish women were employed. There are no data regarding female employees of these occupations in the first two censuses but in April 194219 women were reported to have worked in a group of professions related to ceramics and masonry. A similar situation occurred in jobs such as "manufacturers of musical instruments and toys", "manufacturers of rubber materials" and "engine drivers and stokers". Women were listed in the last kept census and there were not many of them - only one in the first and the last category and two employed in the production of rubber materials.

Slightly more women worked in occupations related to metalworking. In May 1941 there were 20 women, in January 1942-39 and in April 1942 their number increased to 67 . Such activity by women in the above-mentioned professions, which are not very female-friendly, is particularly thoughtprovoking when, for instance, compared to the low participation of women in agriculture. Female chemists were also an interesting phenomenon. Initially, two women were registered as working in this profession, in January 1942 their number rose to 39, whereas in April 1942 it decreased significantly and only 14 women were listed as chemists. It is difficult to explain this downturn of economic activity in the field mentioned above. A relatively large group of women worked in various plants related to the manufacturing of textile products. 133 women were employed there at the beginning of the Kraków Ghetto's existence, in January 1942 their number increased to 193, whereas from April 1942 already 221 women were producing textiles. A group of jobs related

${ }^{42}$ APKr, SMKr 1939-1945, file no. SP Kr 774 (microfilm nr J 13871), Ludność dzielnicy żydowskiej w Krakowie wedtug grup zawodowych i ptci. 
to leather production constituted a separate category. At first, 22 women held such positions, whereas in the next two censuses their number remained at the same level amounting to 30 people. Other jobs, in which the activity of women was not very high, are so-called "food professions" (in which the number of the employed did not exceed 30 people until April 1942), "construction buisness", "graphic professions", and "technicians". It is worth mentioning that Diana Reiter was one of the most well-known women living in the ghetto and holding an architect-engineer diploma. She survived both massive deportations from the Kraków Ghetto and its liquidation, however, she did not make it to the end of the war. She was killed by Amon Göth in Płaszów concentration camp ${ }^{43}$. An increase in employment of women in professions associated with wood and its processing was interesting. Initially, the number of women working this way was very low and limited to eight people; it was similar in January 1942 when only eleven women were registered. However, it increased rapidly to 249 female employees of such professions within the next four months until April 1942. It is difficult to determine what had caused such an increase and whether this trend continued, decreased or further increased. Perhaps this was due to the development of the situation on the war front. Similar changes, but of a limited scope and dynamics, was seen in occupational groups such as "chauffeur and similar" and "sanitation services personnel".

Preserved employment statistics clearly show that the vast majority of women in the Kraków Ghetto were employed in connected with various types of domestic help or in related professions and in areas associated with services. In May 1941 1,797 women were employed in a group of "household workers and related professions" according to statistical data, whereas in January 1942 the number amounted to 2,297 women, and in April 1942 there were 3,633 female employees. For comparison - the number of men employed in this fields did not reached 70. Moreover, 2,450 women were registered in a group of "various helpers" since May 1941, in January 1942 this number decreased to 1,346 people, while in April 1942 there were 2,901 women employed as helpers ${ }^{44}$. Employment in social welfare institutions such as orphanages, hospitals, nursing homes for the poor and the sick, was probably included in

${ }^{43}$ M. Świerkosz, Diana Reiter. Wymazywanie życia, in: Przewodniczka po Krakowie emancypantek, vol. II, ed. E. Furgał, Kraków 2010, pp. 105-121.

${ }^{44}$ APKr, SMKr 1939-1945, file no. SP Kr 774 (microfilm no. J 13871), Ludność dzielnicy żydowskiej w Krakowie wedtug grup zawodowych i ptci. 
these professions. These organisations were a field of particular activity for women. For example Regina Nelken, Anna Feuerstein and Sabina Mirowska among others worked in the orphanage at 8 Krakusa Street ${ }^{45}$. Jobs related to clothing constitute a second group of professions, in which women were employed as seamstresses. According to the first census of May 1941, 599 women were employed in this area, in January 1942 - 874 women, whereas in statistics of April 1942 already 1,045 female employees were listed. "Merchants and clerks" is another important occupational group that included women. In May 1941, there were 557 women employed in these professions, this number increasing up to 786 by January 1942, whereas in April 1942 it decreased again to 539. According to all registers, over 200 women worked in other occupations such as "barbers and beauticians", "restaurant owners" and even more between May 1941 and April 194246.

Craftsmen, working in German and Polish factories, were an occupational group particularly preferred in the Kraków Ghetto, as well as in other ghettos in the General Government. Hence, many plants operated in the ghetto and its neighbourhood such as Oskar Schindler's "Deutsche Emailfabrik" in Zabłocie $^{47}$, Julius Madritsch's confectionary factory ${ }^{48}$ at 3 Rynek Podgórski Street $^{49}$, a brickyard in Bonarka, City Sanitation Department (initially, no

45 AŻIH, file no. 228/55, k. 66-67.

${ }^{46}$ APKr, SMKr 1939-1945, file no. SP Kr 774 (microfilm no. J 13871), Ludność dzielnicy żydowskiej $w$ Krakowie wedtug grup zawodowych $i$ płci.

${ }^{47}$ Pierwsza Małopolska Fabryka Naczyń Emaliowanych i Wyrobów Blaszanych "Rekord" (The First Enamelware and Tinware Products Factory in Lesser Poland -'Rekord") was located there before the outbreak of the Word War II. It was established by 3 Jewish entrepreneurs: Michał Gutman from Będzin, Izrael Kohn from Kazimierz in Kraków and Wolf Luzer Glajtman from Olkusz in March 1937. It was not until 15 January 1940 when Oskar Schindler leased factory buildings in 4 Lipowa Street and 9 Romanowicza Street. He also acquired finished goods and semi-manufactured goods, and then obtained a plant in Lipowa Street. He changed the name of the factory into Deutsche Emailwarenfabrik (German Enamelware Factory) - DEF. Schindler was listed as the legal owner of the company in 1942.

48 The factory made military clothing (uniforms, overalls) and men's underwear. In the initial period only those who had their own sewing machines were allowed to work there. There was a common view that being employed in that factory protected from deportation. Both Polish and Jewish women were employed there. Polish women worked "at Madritsch's" so as not to be deported for forced labour to Germany but only more prosperous Jewish women could afford to work there because they did not receive any money for their efforts. Time had shown that also this place was not a safe haven as almost the entire crew were transported to the extermination camp in Bełżec during the displacement in October 1942.

49 Previously located in Węgierska Street. 
women were employed there, but starting from January 1942 four women worked there, whereas in April 1942 this number increased most probably to 30 female employees), and "Optima" factory. Wachs's factory producing lamps, blowers and stoves was located at 2 Lwowska Street ${ }^{50}$. The activity of these enterprises conformed to a German plan of using Jews as cheap labour force. Also people employed in the arms industry could settle down in the ghetto together with their families. Moreover, there were many branches of various companies in the ghetto. According to the above-mentioned statistics, Jewish women were employed mainly in tailor's and shoemaker's workshops located among others in Węgierska Street (former location of "Optima" building).

There is no doubt that apart from the economic activity, to a large extent, women took care of a house or an apartment, generally described in memoirs as the so-called household. Descriptions of their activities, such as cooking, baking, washing, cleaning or looking after children, often performed after paid work, can be found in the accounts. There are also memories of family celebrations, for which women made cakes and other sweets. A section entitled "Guide for Housewives" was published regularly in a Nazi-supported Gazeta Żydowska (Jewish Magazine) ${ }^{51}$. It contained instructions how to prepare food preserves such as sauerkraut. Among many hints regarding running the house, cleaning, sewing etc. there were also recipes e.g. a green tomato salad, green or red tomato marmalade, lemonade made from lemons, preserves from celery, dill, beetroots, sorrel, green cucumbers, or a marinated salad with green vegetables. Although these culinary ideas sounded extremely attractive and appetising, women probably made no use of them taking into account the possibility of getting food supplies in the ghetto.

The participation of women in the resistance movement in the ghetto was an important aspect in addition to their activities related to paid work, forced labour, as well as to household and family duties. This applies mainly to young people, to a large extent associated with the left-wing movement, as primarily such people engaged in the Jewish Combat Organization ŻOB ${ }^{52}$ activities. Gołda Mirer, Gusta Dränger, Pola Warszawska and Cesia Frymer are such examples. Gołda Mirer and Gusta "Justyna" Dränger had

${ }^{50}$ R. Kotarba, Niemiecki obóz..., p. 17.

${ }^{51}$ Collections of past issues of "Gazeta Żydowska" can be found in Archiwum Państwowe w Krakowie and Archiwum Żydowskiego Instytutu Historycznego.

52 Żydowska Organizacja Bojowa. 
previously been members of the "Akiba" organisation. The publisher of Gusta's diary characterised her as "a young, beautiful and subtle woman. Her feminine features permeated her essence and left a mark on her character. With the creation of ŻOB in Kraków, Gusta-Justyna was the heart of every underground venture and many combat actions resulted from her inspiration and activity" 53 . The issue of women's participation in Jewish underground organisations and the resistance movement has not been thoroughly studied yet and remains an open research question.

Analysing post-war accounts one may notice that to some extent Jews living in the ghetto were getting used to its conditions of life during the initial stage i.e. until the massive deportations of June 1942. A process of "familiarising oneself" with new rules and a reality existing inside the ghetto was taking place. Adaptation is a typical social process. People took on new roles (or at least tried to) imposed by the occupier, in what might be regarded as a peculiar way of surviving the conditions created by the Germans until the end of the war. This is reflected in employment statistics or in stories describing the running of a household, indicating accomodation to the ghetto conditions. Peace and quiet in the ghetto were important elements of a deceptive "programme" of muting negative moods in the district, set by the Germans to facilitate the implementation of further phases - deportation, liquidation of the ghetto and the final extermination of the Jews. Undoubtedly, attempts made to partially reconstruct the infrastructure of social and public life in the ghetto based on the pre-war institutions also constituted an important psychological component making living in the ghetto less difficult. Hence, appearances of normality were created, even if it was only the so-called ghetto normality i.e. limited from every side by the Germans. Obviously, such a process of adaptation did not apply to the entire Jewish population. Therefore, different attitudes were also noticeable in the ghetto but they were not typical behaviour.

Women were involved in all these activities and phenomenon. Even though the place and living conditions forced women to take up work - often very hard physical work - this did not lead to dehumanisation nor to blurring the needs and requirements related to sex. Women tried to take care of their appearance and body and to obtain necessary cosmetics within their means and capabilities. Young women in particular tried to enhance their looks, as is mentioned in their memoirs, in order to have a substitute for the "real" and

\footnotetext{
${ }^{53}$ G. Dränger, Pamiętnik Justyny, Kraków 1946, p. 16.
} 
"normal" life even in the time of the war and the ghetto. In addition, they paid attention to small gestures and compliments directed at them. Halina Nelken recalls how much joy she got from a trifle - a bouquet of lilac brought to an apartment by her father ${ }^{54}$. From time to time she also posed a question in her diary: "Am I/Would I be able to be a great lady?" She even wrote a poem about it ${ }^{55}$. Therefore, the Kraków Ghetto was not only an area where people lived on the brink of poverty. Such struggle was carried out every day but at the same time the ghetto was a place where life kept going on despite difficult conditions and where people tried to sustain and protect life. It was expressed by charity work and nursing activity conducted by women, as well as by education.

Natural life processes were still taking place in the walled district; life and mutual, interpersonal relations existed there. Jews living inside, herded, often dwelling in difficult conditions, still loved and helped each other, as well as quarrelled with or hated each other. At the same time, life in the ghetto revealed various instincts. Apart from the typical attitude - striving to survive by performing work and everyday duties, there were also informers among several thousand Jews who cooperated with the occupier to improve their own life conditions. Certainly, there were also women in this group; however, this aspect has not been adequately researched and described in the light of scarcity of sources.

Stories indicate another important issue - family bonds. As mentioned earlier, Amon Göth ordered that children under 14 years of age should be left in Kinderheim just before the final liquidation of the Kraków Ghetto. A two-year stay in the enclosed district disillusioned its inhabitants with the purpose of the Nazi actions, so it was known that leaving the children in the orphanage meant their death. Parents faced a tragic choice. They tried many various ways to take their offspring to the Płaszów camp. However, the vast majority of parents, particularly of the youngest children, was obliged to send them to Kinderheim. A man named Marek related events he then witnessed: "mothers madly walked through the street of the ghetto, fathers tried to learn what would happen to children and old people from a head of Ordungsdienst but they only shrugged their shoulders, they were not able to help or to advise. It could be sensed that a terrible moment for the families

\footnotetext{
${ }^{54}$ H. Nelken, Pamiętnik z..., p. 126.

${ }^{55}$ Ibid, pp. 127-128.
} 
was coming, that (...) SS-Untersturmführer Amon Göth would spare no effort nor bother to annoy Jews as much as possible and to separate families" ${ }^{\prime \prime 6}$. One can notice a clear sense of helplessness towards ongoing events, which led to various attitudes of parents. Witnesses mentioned difficult choices, which in their opinion affected mainly women due to their natural maternal instinct. Janka Warszawska ${ }^{57}$, who was a teenager at that time, recalled: "There were also the mothers who denied their own children. They did not want to die. But there were many more who chose voluntary death. There were a lot of cases when both father and mother decided to die for one child"58. To confirm her observations, she told a story of a married couple - tenants of a house she lived in. They both stayed in the ghetto together with their little daughter despite the fact that they were assigned to the camp. Some mothers initially left their children in Kinderheim and then returned to collect them - "they hurried to take their children away from there [from the house for children], while there was still time - one could feel a coming danger" 59 . Sometimes, despite a clear order to abandon the children, women kept them by themselves all the time - "When a mother refused to leave a child, they [Germans] shot at her, and Göth himself held a gun" 60 . Therefore, mothers voluntarily decided to die so as not to leave the children alone and be with them until the very end, as well as to offer them a bit of security in these difficult moments. According to witnesses, it was mostly women who left ordered rows ready to go to Płaszów, realising at the same time that their choice meant a death sentence. While leaving the ranks, they obliged their husbands to stay in there and go to the camp $^{61}$.

To sum up, apart from the changes of the traditional position and role of Jewish woman during the occupation, as well as changes in the family structure, women took on new occupational roles in such a difficult reality. They worked in various places irrespective of their background and education in order to survive and support or feed their families. Women were also

${ }_{56}$ AŻ̇H, file no. 301/4669, Relacja świadka o imieniu Marek.

${ }^{57}$ She was 14 years old on the day of giving her testimony (1945).

${ }_{58}$ APMAB, Memories, t. 192/1046, (inv. 173940). Relacja Janki Warszawskiej.

${ }^{59}$ AŻIH, file no. 301/4669, Relacja świadka o imieniu Marek.

${ }^{60}$ IPN Kr, OKŚZpNP Kr, file no. Ds. 38/67 t. 1, k. 21; IPN Kr, OKŚZpNP Kr, file no. Ds. 38/67 t. 2, k. 11. Zeznania Hermana Ladnera.

${ }^{61}$ A. Biberstein, Zagłada Żydów w Krakowie, Kraków 2001, p. 97. 
active in the resistance movement organised in the ghetto, often holding high positions. One should also take into account that the ghetto polarised attitudes - there were female informers and those who chose their private goals over the family or friends. However, these research areas require additional archive and library searches due to insufficient source material, as well as problems related to a widely comprehended sphere of morality and validity of decisions and alternative choices, although they remain within the scope of my interest. Similarly, issues associated with everyday rituals, sexuality, pregnancy and births, as well as the religious aspect in a broader perspective are areas unexplored by scholars. Unfortunately, in archival sources researchers will not find answers for many important questions. For example, there is almost no information in the written accounts on Orthodox Jews. This is mainly due to the fact that, on the one hand, their cultural and social habits made survival more difficult and, on the other hand, few of them bothered about leaving written testimonies since they were basically not interested in secular history. Stories were mostly told by assimilated Jews speaking Polish (and not Yiddish) and those who abandoned Jewish traditions and Judaism prevail. Topics related to the ritual and symbolic sphere are clearly missing. It is difficult to find any mention of sexual activity, pregnancy - including unwanted pregnancy, the issue of abortion and prostitution in the analysed accounts. And an attempt to create a narrative based on other descriptions of the life in the ghettos and camps in the General Government might lead to a false picture of the situation of Jewish women in occupied Kraków.

The article submitted by the author to the editor has been translated by Bożena Koczurek 